\title{
Early experience with implantation of the new biological Trifecta valve
}

\author{
Radosław Smoczyński ${ }^{1}$, Wojciech Sarnowski ${ }^{1}$, Adrian Kłapyta ${ }^{2}$, Bartłomiej Szafron ${ }^{1}$, Dariusz Kosior ${ }^{3,4}$, \\ Sławomir Sypuła ${ }^{3}$, Dominik Drobiński ${ }^{1}$, Zygmunt Kaliciński ${ }^{1}$, Anna Witkowska ${ }^{1}$, Piotr Suwalski ${ }^{1,4}$ \\ ${ }^{1}$ Department of Cardiac Surgery, Central Clinical Hospital MSW, Warsaw \\ ${ }^{2}$ Medical University of Warsaw \\ ${ }^{3}$ Department of Cardiology, Central Clinical Hospital MSW, Warsaw \\ ${ }^{4}$ Kazimierz Pulaski University of Technology and Humanities in Radom
}

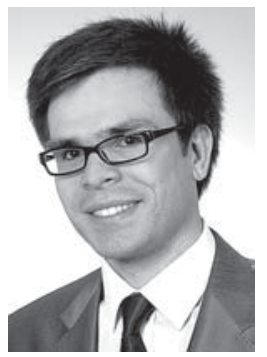

Kardiochirurgia i Torakochirurgia Polska 2013; 10 (2): 105-109

\begin{abstract}
Introduction: Aortic stenosis (AS) is the most common valvular disease in Europe and the USA, and the second indication for cardiac surgery. The effective treatment of AS is based mainly on surgical valve replacement using either a mechanical or a biological prosthesis. This study describes the early experience with the new biological valve Trifecta (St. Jude Medical, Inc.). Material and methods: The study included 38 elective patients who underwent aortic valve replacement (AVR) or AVR with concomitant procedures. Pre- and postoperative comorbidities/complications, blood samples and echo were collected. Before discharge from the hospital all patients had vitamin $\mathrm{K}$ antagonist therapy for three months after the operation.

Results: In all patients with AVR (19 patients) or AVR plus ascending aorta replacement (3 patients) or AVR plus non-coronary sinus plasty and ascending aorta replacement (1 patient) or Bentall de Bono self-made conduit procedures (1 patient) minimally invasive technique was used. Trifecta valves were successfully implanted in all patients, including in AVR with combined procedures (14 patients). Mean overall postoperative transvalvular gradient was $13 \mathrm{~mm} \mathrm{Hg}$ in small roots (valve size 19 and $21 \mathrm{~mm}$ ). Valve size $23 \mathrm{~mm}$ or more had single digit mean gradients. Total mortality rate was 5.2\% (2 patients), and occurred among high-risk patients undergoing combined procedures.

Conclusions: AVR using Trifecta is feasible and safe. Low postoperative mean gradients, especially in small roots (valve size 19 and $21 \mathrm{~mm}$ ), are encouraging. Further investigations are necessary to confirm potential durability and positive impact on myocardial mass regression.
\end{abstract}

Key words: Trifecta, AVR, minimally invasive, biological valve.

\section{Streszczenie}

Wstęp: Stenoza aortalna to najpowszechniejsza choroba zastawek serca w Europie oraz Stanach Zjednoczonych i druga pod względem częstości występowania przyczyna interwencji kardiochirurgicznych. Skuteczne leczenie polega najczęściej na wymianie zastawki aortalnej na sztuczną zastawkę mechaniczną lub biologiczną. Prezentowane badanie pokazuje wczesne doświadczenia z nowym typem zastawki aortalnej Trifecta (St. Jude Medical, Inc.).

Materiał i metody: Do badania włączono 38 kolejnych pacjentów, u których wykonano operację wymiany zastawki aortalnej (aortic valve replacement - AVR) lub AVR z operacją towarzyszącą. Przed zabiegiem, śródoperacyjnie i po operacji zbierano dane dotyczące: wyników badań biochemicznych krwi, zdarzeń niepożądanych, parametrów echokardiograficznych. U wszystkich pacjentów zastosowano profilaktykę zatorowo-zakrzepową antagonistami witaminy $\mathrm{K}$ w ciągu 3 miesięcy po operacji. Wyniki: U wszystkich pacjentów poddanych AVR (19 pacjentów) lub AVR z towarzyszącą wymianą aorty wstępującej (3 pacjentów) i dodatkową plastyką zatoki Valsalvy (1 pacjent) oraz operacją metodą Bentall de Bono z konduitem wykonanym śródoperacyjnie (1 pacjent) wybrano technikę małoinwazyjną. U wszystkich chorych skutecznie implantowano zastawkę aortalną Trifecta, w tym także u 14 pacjentów z inną niż wymieniona wyżej operacją towarzyszącą. Średni pooperacyjny gradient przez protezę wyniósł $13 \mathrm{~mm} \mathrm{Hg}$ u pacjentów z małym ujściem aortalnym (rozmiar zastawki $19 \mathrm{~mm}$ i $21 \mathrm{~mm}$ ). W przypadku rozmiaru $23 \mathrm{~mm}$ i większego średni gradient był liczbą jednocyfrową. Ogólna śmiertelność wynosiła 5,2\% (2 pacjentów) i dotyczyła chorych wysokiego ryzyka z chorobami towarzyszącymi w złożonych operacjach serca.

Wnioski: Wymiana zastawki aortalnej przy użyciu protezy biologicznej Trifecta jest wykonalna i bezpieczna. Niski pooperacyjny gradient w szczególności w małych ujściach aortalnych (19 mm i $21 \mathrm{~mm}$ ) jest obiecujący. Niezbędne są dalsze badania,

Address for correspondence: lek. Radosław Smoczyński, Klinika Kardiochirurgii, Centralny Szpital Kliniczny MSW w Warszawie, ul. Wołoska 137, 02-507 Warszawa, tel. +48 608459 676, e-mail: radek.sm@gmail.com 


\section{Introduction}

The first biological valves were successfully implanted in 1962 by Ross and Barrat-Boyes, and were called homografts or allografts. Those valves were derived from cadavers, unlike autografts, i.e. autologous grafts from the pulmonary artery, which were successfully implanted for the first time in 1967 [2]. In the 1960s the method of porcine preservation was developed by Carpentier and coworkers. A little later bovine valves were preserved in glutaraldehyde, which was a milestone in the field of bioprostheses. The advantages of all bioprostheses included reduced incidence of thromboembolic complications and no need for anticoagulation treatment. Tissue valve technology has been developed over the past 50 years and includes anticalcification and fixation methods, hemodynamic performance, durability or design. That is why the number of bioprostheses implanted worldwide has risen from $30 \%$ to $85 \%$ over the past 15 years and the biological stented valves are the main prostheses used for aortic valve replacement (AVR) [3]. This also applies to Poland, where the number of implanted biological stented valves has increased significantly from $32 \%$ to $53 \%$ over the past 5 years [4].

The study presents early single center experience with the new Trifecta valve (St. Jude Medical, Inc.).

\section{Material and methods}

The prospective study included 38 elective patients who underwent aortic valve replacement using the Tri-

Tab. I. Demographic data

\begin{tabular}{lc} 
Demographic data $(n=38)$ & $64.3 \pm 11.7$ \\
\hline Age (years) & 55.3 \\
\hline Male $(\%)$ & $29.8 \pm 4.1$ \\
\hline BMI $\left(\mathrm{kg} / \mathrm{m}^{2}\right)$ & 10.5 \\
\hline Endocarditis (\%) & 47.4 \\
\hline CAD (\%) & 63.2 \\
\hline Hypertension (\%) & 13.2 \\
\hline Renal failure (\%) & 10.5 \\
\hline COPD (\%) & 10.5 \\
\hline Previous PTCA (\%) & 21.1 \\
\hline AF $(\%)$ & 18.4 \\
\hline Diabetes (\%) & $2.6 \pm 0.5$ \\
\hline NYHA class & $56.5 \pm 7.1$ \\
\hline EF (\%) & $7.58 \pm 6.15$ \\
\hline Log Euroscore (\%) & $2.57 \pm 2.08$ \\
\hline EuroSCORE II (\%) & \\
\hline BMI - body mass index; CAD - coronary artery disease; PTCA - percutaneous \\
transluminal coronary angioplasty; AF - atrial fibrillation; NYHA - New York \\
Heart Association; EF - ejection fraction
\end{tabular}

aby potwierdzić potencjalną trwałość i pozytywny wpływ zabiegu na regresję mięśnia sercowego.

Słowa kluczowe: Trifecta, AVR, operacje małoinwazyjne, zastawka biologiczna.

fecta valve between March 2011 and December 2012 in the Central Clinical Hospital of the Ministry of Interior in Warsaw. The mean age was $64.4 \pm 11.7$ within 21 male patients (55\%). The main patients' comorbidities were hypertension (63\%), diabetes (18.4\%), and coronary artery disease (47\%). All demographic data are presented in Table I. The main cause of surgical intervention was severe aortic stenosis (71\%) and aortic regurgitation due to endocarditis (10.5\%) or aortic aneurysm (13.1\%). The overall mean aortic gradient was $41.3 \pm 18.3 \mathrm{~mm} \mathrm{Hg}$ and overall aortic orifice area was $0.9 \pm 0.5 \mathrm{~cm}^{2}$. The mean Logistic EuroSCORE was $7.58 \pm 6.15 \%$ and EuroSCORE II $2.56 \pm 2.08 \%$.

The less invasive technique was the purpose of the surgical access but it depended on the concomitant procedure. Upper mini-sternotomy was preferred for isolated AVR or ascending aortic replacement with AVR. The technique consists of 7-9 cm skin incision and V-shape upper-sternotomy maximally reaching the $4^{\text {th }}$ rib. For better operative area visualization, the vein cannula and vent were protracted through the $2 \mathrm{~cm}$ incision under the xiphoid process which was also used for a mediastinal drainage after the procedure. In other cases a classical median sternotomy was performed. A cardiopulmonary bypass and mild hypothermia were applied in combination with cold blood or crystal cardioplegia. The native degenerated aortic valve was removed and the annulus was decalcified. 2-0 Ethibond horizontal mattress stitches with pledgets on the ventricular side were used for supra-annular valve implantation. The sternal closure technique was double criss-cross sternal wiring.

Prior to discharge from hospital, Trifecta valves were examined by transthoracic echo in all patients. Vitamin $\mathrm{K}$ antagonists were administered in a 3-month therapy protocol as antithrombotic prophylaxis.

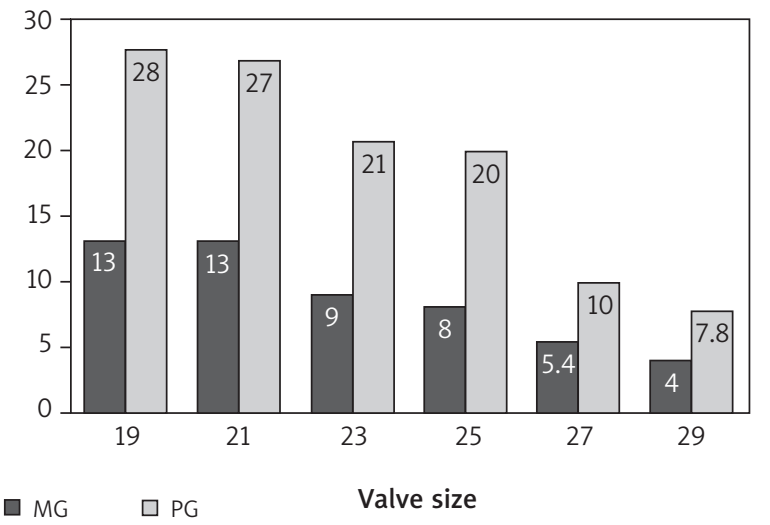

Fig. 1. Average mean gradient (MG) and average peak gradient (PG) in postoperative transthoracic echo in comparison with valve size (19, 21, 23, 25, 27 and $29 \mathrm{~mm})$ 
Statistical analysis was performed by means of StatSoft, Inc. (2007) STATISTICA (data analysis software system), version 8.0. Correlations, descriptive statistics, T-test for independent samples and T-test for dependent samples were basic statistical calculations.

\section{Results}

All Trifecta valves were successfully implanted. Upper mini-sternotomy was done in 25 patients (66\%) either for isolated AVR (20 patients) or AVR with ascending aorta replacement (5 patients). One patient had a combined procedure that consisted of non-coronary sinus repair with AVR and supra-coronary ascending aorta replacement through upper mini-sternotomy. In addition one Bentall de Bono procedure using a self-made conduit made with Trifecta sewn into the Dacron graft was performed through upper mini-sternotomy (Fig. 2). There was no conversion to full median sternotomy. Other concomitant procedures were coronary artery bypass graft (CABG) (8 patients), mitral valve replacement (3 patients), and tricuspid repair (2 patients) (Table II).

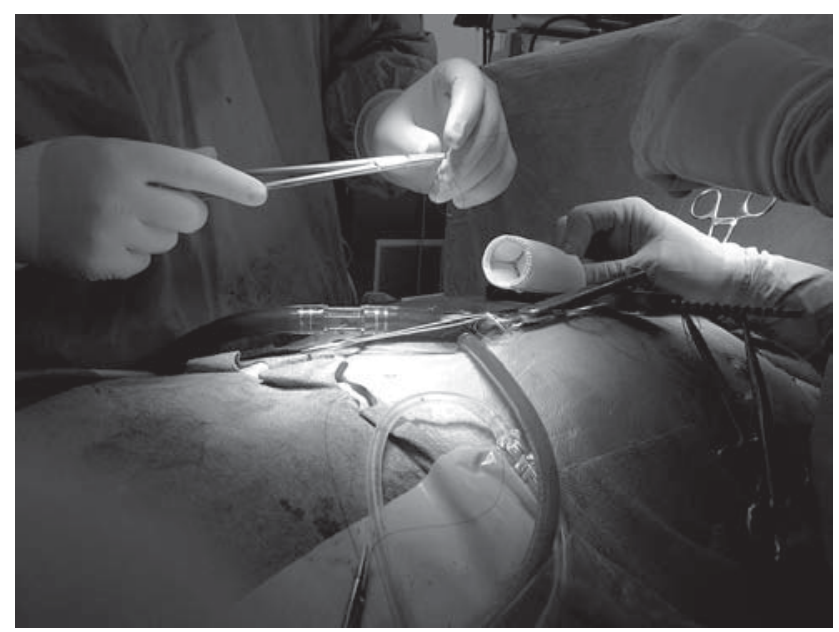

Fig. 2. Bentall de Bono procedure using self-made conduit made with Trifecta sewn into the Dacron graft through upper mini-sternotomy

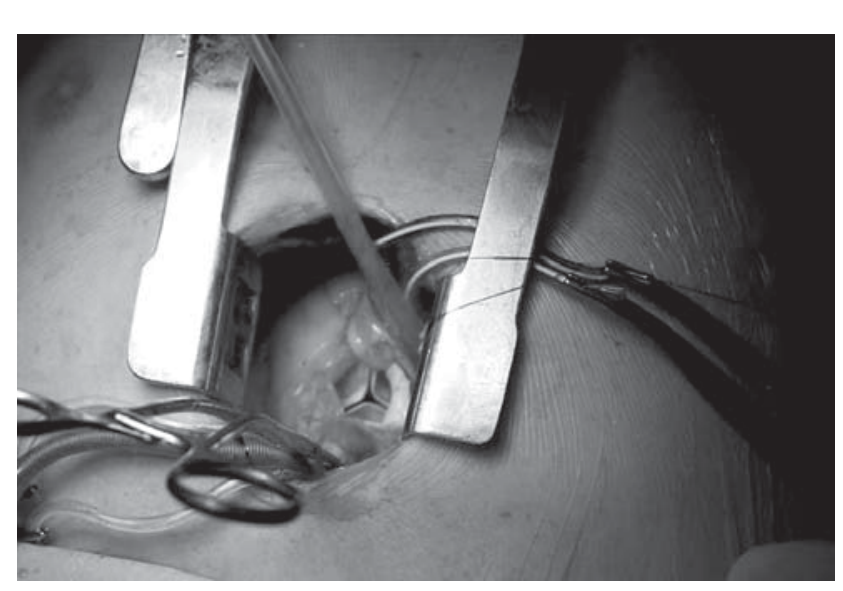

Fig. 3. Intraoperative picture after Trifecta implantation
In 1 patient with a narrow aortic root, aorta enlargement using a polytetraflouroethylene (PTFE) patch was needed, which was associated with the relatively high profile of the prosthesis. Another patient had symptomatic PPM (patient prosthesis mismatch) which was the indication for reoperation; the other type of biological aortic prosthesis was replaced with the same size of Trifecta $(19 \mathrm{~mm})$ reaching significantly lower gradients and greater EOA (effective orifice area) (Fig. 3).

The mean cardiopulmonary bypass (CPB) time was $133.1 \pm 50.2 \mathrm{~min}$ and the mean ACC time was $93.1 \pm 35.5 \mathrm{~min}$, strongly influenced by a few complicated procedures in that small cohort. Postoperative total drainage was $605.5 \pm 83 \mathrm{ml}$; however, less invasive access correlated with lower bleeding (433.6 \pm 252.9 vs. $935 \pm 364.1 \mathrm{ml} ; p=0.00003$ ) and lower blood transfusion rate ( $0.8 \pm 1.1$ vs. $2.0 \pm 1.7$ units; $p=0.01)$. Mean intubation time was $10.4 \pm 12.4$ hours (Table III).

Postoperative transthoracic echo showed good function of the Trifecta valve and a transvalvular gradient decrease without significant paravalvular leak among all patients. In small roots (Trifecta valve size $19 \mathrm{~mm}$ and $21 \mathrm{~mm}$ ) the mean

Tab. II. Intraoperative data

\begin{tabular}{ll} 
Intraoperative data & \\
Isolated AVR (\%) & 50 \\
\hline AVR + ascending aorta replacement (\%) & 7.9 \\
\hline $\begin{array}{l}\text { AVR+ non-coronary sinus plasty + ascending aorta } \\
\text { replacement (\%) }\end{array}$ & 2.6 \\
\hline Bentall de Bono self-made conduit (\%) & 2.6 \\
\hline AVR + CABG (\%) & 21 \\
\hline AVR + MVR/P (\%) & 7.9 \\
\hline AVR + TVP (\%) & 5.3 \\
\hline Re-AVR (\%) & 2.6 \\
\hline Valve size & $22.3 \pm 2.6$
\end{tabular}

AVR - aortic valve replacement; CABG - coronary artery bypass graft; MVR/P mitral valve repair/plasty; TVP - tricuspid valve plasty

Tab. III. Postoperative data

\begin{tabular}{lc} 
Postoperative data & \\
ACC time [mini-AVR] (min) & $93.1 \pm 35.5[77.1 \pm 22.6]$ \\
\hline CPB time [mini-AVR] (min) & $133.1 \pm 50.2[112.0 \pm 32.1]$ \\
\hline Intubation time (h) & $10.1 \pm 13.2$ \\
\hline ICU stay (days) & $3.37 \pm 1.9$ \\
\hline Total in-hospital stay (days) & $10.7 \pm 3.3$ \\
\hline Blood transfusion (units) & $1.1 \pm 1.4$ \\
\hline FFP (units) & $1.4 \pm 2.0$ \\
\hline Total drainage (ml) & $605.5 \pm 83$ \\
\hline Tamponade (\%) & $2.6(1$ patient) \\
\hline Wound infection (\%) & $5.3(2$ patients) \\
\hline Delirium (\%) & $7.9(3$ patients) \\
\hline Death (\%) & $5.2(2$ patients) \\
\hline
\end{tabular}

ACC - aortic crossclamp; CBP - cardiopulmonary bypass; ICU - Intensive Care Unit; FFP - fresh frozen plasma 
gradient was $13 \pm 7.2 \mathrm{~mm} \mathrm{Hg}$. Valve size $23 \mathrm{~mm}$ or more had single digit mean gradients (Fig. 1).

The observed complications were tamponade (1 patient), wound infection ( 2 patients), delirium (3 patients), and acute renal insufficiency (1 patient). Total 30-day inhospital mortality was $5.2 \%$ (2 patients). The first patient died due to postoperative stroke complicated by acute pneumonia and sepsis that was treated unsuccessfully with extracorporeal membrane oxygenation (ECMO). The second death was caused by an abdominal complication which did not responded to treatment in a patient after AVR, mitral valve plasty (MVP) and CABG.

\section{Discussion}

Trifecta is a next-generation stented bovine pericardial heart valve for supra-annular placement with advanced design (Fig. 1). The valve's unique features include a fatigueresistant titanium stent with pericardium to reduce the risk of leaflet abrasion and structural valve deterioration (SVD) during the cardiac cycle. Furthermore, minimizing mechanical stress may play a key role in the tissue valve's ability to resist calcification $[5,6]$. To minimize calcification and deterioration, which can occur after implantation due to the presence of phospholipids in the tissue lipid deposits and elevated calcium metabolism, Linx anticalcification (AC) technology has been used. The durability of the Trifecta bioprosthesis was assessed in vitro by means of accelerated lifetime cyclic testing under dynamic conditions. Testing was performed on a valve at 1000 beats per minute with a mean aortic pressure gradient of $120+20 /-0 \mathrm{~mm}$ $\mathrm{Hg}$. The results showed freedom from valve failure (reliability \%) after 200, 400, 600 million cycles $-99.2 \%$ (5 years in vivo), $94.3 \%$ (10 years), 82.9 (15 years) respectively, and a fully functional valve after 1.25 billion cycles (approximately 31 years). There is an interesting design detail the elimination of alignment stitches at the top of commissures - thanks to which the valve gives good hemodynamic performance (large EOA, Fig. 1), which has been demonstrated both in this study and in other available clinical single and multicenter trials.

In a clinical trial with two-year follow-up at the Hospital of the University of Pennsylvania, 100 Trifecta valves were implanted by Dr. Bavaria's team as part of a prospective Food and Drug Administration (FDA) study between August 2007 and October 2009. Patients scheduled for AVR who met the study eligibility criteria received a Trifecta valve. Echocardiography, New York Heart Association (NYHA) classification and physical examination were used to assess hemodynamic performance and valve durability. The results show good hemodynamics which remained stable 2 years following the procedure. In $23 \mathrm{~mm}$ valve size $(n=35)$, the average mean gradients at discharge, 1 year, and 2 years were $7.9 \pm 3.8 \mathrm{~mm} \mathrm{Hg}, 7.8 \pm 3.3 \mathrm{~mm} \mathrm{Hg}$, and $6.6 \pm 4.4 \mathrm{~mm} \mathrm{Hg}$, respectively. Measured indexed effective orifice area (EOAl, $\mathrm{cm}^{2} / \mathrm{m}^{2}$ ) remained stable during the study period. For $23 \mathrm{~mm}$ valve size $(n=35)$, EOAls were $0.97 \pm 0.18,0.84 \pm 0.19$, and $0.95 \pm 0.14$. The rate of PPM
$($ EOAI < 0.65$)$ was $3.7 \%$ at two years. NYHA classification at 6 months, 1 year, and 2 years after implantation demonstrated notable improvement in quality of life compared with preoperative assessments [7, 8]. These results confirm findings from a multicenter, multi-country (USA, Canada, Europe), prospective, non-randomized observational study with 1,022 Trifecta $^{\circledR}$ valves implanted between June 2007 and November 2009. The most common valve size implanted was $23 \mathrm{~mm}(n=335,33 \%)$, preoperatively $49.3 \%$ of subjects were NYHA class III or IV, and at 1 year postoperatively $98.9 \%$ were NYHA class I or II. The average mean gradients for all sizes (19 $\mathrm{mm}$ to $29 \mathrm{~mm}$ ) were $\leq 10.7 \mathrm{~mm}$ $\mathrm{Hg}$ at one year postoperatively. Large effective orifice areas EOAls $\geq 0.85 \mathrm{~cm}^{2} / \mathrm{m}^{2}$ across all valve sizes reduce the risk of patient-prosthesis mismatch (PPM). Regurgitation at discharge was none or trivial in nearly all subjects, and $97 \%$ of them had either no or trivial regurgitation at one year [9]. In comparison with other bioprostheses in the same one-year follow-up period, the results for Trifecta are encouraging. In a prospective randomized study with Edwards Perimount Magna (EPM) and Medtronic Mosaic (MM) valves (23 mm size), the average mean gradients after 12 months were $10.3 \pm 3.8 \mathrm{~mm} \mathrm{Hg}(E P M)$ and $15.8 \pm 6.2 \mathrm{~mm} \mathrm{Hg}(M M)$, whereas indexed effective orifice areas (EOAls) were $1.06 \pm 0.17 \mathrm{~cm}^{2}$ (EPM), and $0.88 \pm 0.07 \mathrm{~cm}^{2}(\mathrm{MM})$ [10]. Also in comparison with stentless and sutureless bioprostheses, Trifecta does not differ from the others. In the ASSERT prospective, multicenter, randomized 12-month trial, a stentless Freestyle valve (Medtronic, Inc) was compared with a stented Mosaic valve (Medtronic, Inc). The authors reported average EOAI $\left(\mathrm{cm}^{2} / \mathrm{m}^{2}\right)$ after one year of $0.72 \pm 0.21$ for stented, and $0.96 \pm 0.32$ for stentless valve bioprostheses [11]. Another prospective, randomized, 12-month controlled trial comparing stentless vs. stented valve bioprostheses (Sorin Freedom vs. Sorin More) showed an average EOAI $\left(\mathrm{cm}^{2} / \mathrm{m}^{2}\right)$ of $0.8 \pm 0.2$ for stented and $1.1 \pm 0.3$ for stentless valve bioprostheses [12]. Pillai et al. reported early (2-year trial) clinical results for the $3 \mathrm{f}$ Enable sutureless bioprosthesis with an average EOAI $\left(\mathrm{cm} / \mathrm{m}^{2}\right)$ of $1.0 \pm 0.4$ [13]. To conclude, the Trifecta valve has shown good performance among stented bioprostheses, comparable with stentless/sutureless ones.

Implantation of the Trifecta valve requires basically the same standard technique, which can be considered an important advantage especially in the minimally invasive technique. However, due to the relatively high profile it can be difficult in patients with a narrow sino-tubular junction, which needs precaution. In our experience, however, it happened only once and was easily solved with aortic patch plasty.

Hemodynamic parameters both in our study and other Trifecta studies turned out to be very satisfactory. The good hemodynamic results in small valve sizes $(19-21 \mathrm{~mm})$ make Trifecta a realistic option for patients with a small annulus. While Trifecta is undoubtedly a promising valve on the bioprosthesis market, it should be noted that further follow-up is needed to assess its long-term durability, hemodynamic performance and adverse event rates. 


\section{Acknowledgements}

The study was conducted using independent financial resources of the Department of Cardiac Surgery, Central Clinical Hospital MSW, Warsaw, Poland

Adrian Kłapyta is a doctoral student at Warsaw Medical University, formerly working at St. Jude, Inc. Other authors declare no conflict of interest.

\section{References}

1. Faggiano P, Antonini-Canterin F, Baldessin F, Lorusso R, D'Aloia A, Cas LD. Epidemiology and cardiovascular risk factors of aortic stenosis. Cardiovascular Ultrasound 2006; 4: 27.

2. Hopkins R, Louis J, Corcoran P. Ross' first homograft replacement of the aortic valve. Ann Thorac Surg 1991; 52: 1190-1193.

3. Cremer J, Schöttler J, Petzina R, Hoffmann G. Stented bioprostheses in aortic position. HSR Proc Intensive Care Cardiovasc Anesth 2012; 4: 83-87.

4. Maruszewski B, Tobota Z, Zembala M, Sitko T. Report of the National Register of Cardiac Surgery KROK. Kardiochirur Torakochirur Pol 2012; 9: 283.

5. Schoen F, Levy R. Founder's Award, $25^{\text {th }}$ Annual Meeting of the Society for Biomaterials, perspectives. Providence, RI, April 28-May 2, 1999. Tissue heart valves: current challenges and future research perspectives. J Biomed Mater Res 1999; 47: 439-465.

6. Liao KK, Li X, John R, Amatya DM, Joyce LD, Park SJ, Bianco R, Bolman RM $3^{\text {rd }}$. Mechanical stress: An independent determinant of early bioprosthetic calcification in humans. Ann Thorac Surg 2008; 86: 491-495.
7. Bavaria J, Desai N, Burtch K, Vuong D, et al. Two-Year Results of the St. Jude Medical Trifecta Pericardial Aortic Valve Bioprosthesis. Presented at The Society for Heart Valve Disease, Barcelona, 2011.

8. Bavaria J, Szeto W, Burtch K, Moyer EP, Morris RJ, Desal NJ. Early Results of the St. Jude Medical Trifecta Pericardial Aortic Valve Bioprosthesis. Presented at the Heart Valve Society of America 6th Annual Scientific Session, New York 2010

9. Trifecta Valve - 2011 Clinical Compendium, One Year Data. On-line: http://sjmcentral.sjm.com/sites/PRC/Resources/Trifecta

10. Dalmau MJ, María González-Santos J, López-Rodríguez J, Bueno M, Arribas A, Nieto F. One year hemodynamic performance of the Perimount Magna pericardial xenograft and the Medtronic Mosaic bioprosthesis in the aortic position: a prospective randomized study. Interact Cardiovasc Thorac Surg 2007; 6: 345-349.

11. Perez de Arenaza D, Lees B, Flather M, Nugara F, Husebye T, Jasinski $M$, Cisowski M, Khan M, Henein M, Gaer J, Guvendik L, Bochenek A, Wos S, Lie M, Van Nooten G, Pennell D, Pepper J; ASSERT (Aortic Stentless versus Stented valve assessed by Echocardiography Randomized Trial) Investigators. Randomized comparison of stentless versus stented valves for aortic stenosis: effects on left ventricular mass. Circulation 2005; 112: 2696-2702.

12. Dunning J, Graham RJ, Thambyrajah J, Stewart MJ, Kendall SW, Hunter S Stentless vs. stented aortic valve bioprostheses: a prospective randomized controlled trial. Eur Heart J 2007; 8: 2369-2374.

13. Pillai R, Ratnatunga C, Soon JL, Kattach H, Khalil A, Jin XY. 3f Prosthesis Aortic Cusp Replacement: Implantation Technique and Early Results. Asian Cardiovasc Thorac Ann 2010; 18: 13-18 